\title{
ADVANTAGES AND LIMITATIONS OF LINEAR AND NONLINEAR BREAK-EVEN MODELS
}

\author{
Danijela Martinovic* \\ Faculty of Economics University of Sarajevo, Sarajevo, Bosnia and Herzegovina
}

The break-even point model is a well-known instrument for determining target production, income and costs for the purpose of gaining a zero profit. Although it is a concept that was present in the literature as early as in the late XIX century, the break-even point is applied in the contemporary business practice even today. This paper aims to demonstrate the advantages and limitations of the traditional (linear) and contemporary (nonlinear) break-even models. Particular attention is paid to the assumptions needed for a successful application of both models. The frequency of the use of the break-even point, limitations and assumptions were studied on a sample of 100 manufacturing enterprises in Bosnia and Herzegovina. The research study has revealed management's awareness of the potentials for applying the break-even point concept and the need to use the modern models that include assumptions pertaining to change in the key variables in the model. This results in the need to design such nonlinear, dynamic and stochastic models that best represent the dynamic conditions of contemporary business.

Keywords: break-even point, linear and nonlinear model, cost classification, application in Bosnian and Herzegovinian enterprises

\section{JEL Classification: M210}

\section{INTRODUCTION}

The subject matter of the research study conducted in this paper is the presentation of the break-even point concept and the analysis of the advantages and limitations of the application of the linear (traditional) and nonlinear (contemporary) models of the breakeven point. The research study is aimed at presenting

* Correspondence to: D. Martinovic; Faculty of Economics University of Sarajevo, Trg oslobodjenja 1, 71000 Sarajevo, Bosnia and Herzegovina;

e-mail: danijela.martinovic@efsa.unsa.ba the applicability of these models in the business practice of Bosnian and Herzegovinian enterprises and the assumptions about their successful application.

The theoretical and applicative research studies were aimed at improving the theoretical basis of the models, diagnosing the actual conditions in the Bosnian and Herzegovinian business practice related to the application of the break-even point model, and the improvement of the implementation of break-even point analysis in business practice. 
Break-even point models are significant planning and controlling instruments related to making a series of business decisions. Based on the research study carried out in a hundred manufacturing enterprises in Bosnia and Herzegovina, the paper presents the frequency of the application of the break-even point in making the described business decisions, or more accurately in the analysis of business performance, making decisions on the cost-effectiveness of introducing new products in the product range, the replacement of the existing products with new ones, product recalls, making investment decisions, determining business liquidity and planning and controlling the existing results. The research results showed that, on average, the surveyed enterprises had assessed the analysis using the break-even point as a significant tool for making all described decisions.

The results of the theoretical and empirical research studies have revealed the existence of a series of assumptions about the successful application of the break-even point with a focus on the need to efficiently classify costs and analyze the nonlinearity of revenues and expenditures. Therefore, the second aspect of the research study was focused on the frequency, ways and problems of the cost classification, as well as the need to monitor and forecast the nonlinearity of revenues and expenditures.

The following hypotheses were tested:

H1: Break-even point models have a potential for a broad applicative use in the business practice of Bosnian and Herzegovinian enterprises, regardless of their size and sectoral affiliation.

H2: An efficient cost classification, as well as the awareness of the existence of the nonlinearity of revenues and expenditures, contributes to the successful application of the break-even point.

H3: Managers have problems when classifying costs and estimating future revenues and costs and their (non)linearity.

The analysis and interpretation of the results is based on descriptive statistics.
The paper consists of the theoretical presentation of the break-even point (Chapter 2) and the presentation of the traditional (Chapter 3) and contemporary models of the break-even point (Chapter 4). Particular attention was paid to the assumptions about the application of such traditional and contemporary models. The paper ends with the empirical presentation of the research results (Chapter 5) and a concluding discussion.

\section{BREAK-EVEN POINT CONCEPT}

The break-even point (the cost-efficiency threshold, the profitability threshold, the zero point, the dead point, a CVP analysis) is a situation in an enterprise's business when its sales income (operating income, i.e. production value) becomes equal to the costs incurred in the production of the given products (Kilger, 1993, 802).

The break-even point primarily implies the quantity of the products that an enterprise has to manufacture and sell in order to cover its costs. The break-even point defined in this way is a natural expression of the described concept. It also implies the existence of homogenous production, i.e. the production of a single kind of a product. The break-even point may also be understood as the degree of the capacity utilization necessary for manufacturing a required quantity of products. Besides, business operations, i.e. reaching a cost coverage at a lower degree of the capacity utilization, implies an efficient use of resources, i.e. it creates room in the enterprise for it to utilize a greater part of the remaining capacity in order to gain a profit. The transformation of the break-even point into value indicators requires the presentation of production by means of the income necessary to cover the costs, a coverage contribution, i.e. a profit margin, etc. Naturally, beside the algebraic way of presentation, the break-even point can be presented graphically as well. The basis for both the graphic presentation and the mathematical calculation of the break-even point and a number of supplemental (derived) indicators can be found in traditional economic theories, classical and neoclassical theories. 
The break-even point is a significant instrument for strategic planning related to making decisions on the quantity of the products that need to be produced and sold so as to cover costs. However, it is also used in making decisions on the depth and scope of the product range, change in the sale price, cost management, investment decisions (Nikolaevič, 2015, 18), namely in all interfaces between benefits and costs, or the "what-if" scenarios pertaining to making decisions on business alternatives (Gean \& Gean, 2015, 127).

Apart from the above-said, an analysis using the break-even point provides managers with an insight into the size and relations among its key categories: the cost structure, the production volume and a profit (Gean \& Gean, 2015). It is the analysis using the break-even point that helps an enterprise achieve its target profit, since the goal of the analysis is not "the achievement of the break-even point, but rather the maximization of the periodical business result." (Janjić, Todorović i Jovanović, 2010, 561) The breakeven point, i.e. its analysis, is also applicable in the determination of an enterprise's liquidity (Mehar, 2005, 259-271) and financial position.

That revenue, cost and profit factors (CVP factors) can affect the financial structure of a firm is accepted in the finance literature (McCabe, 1979, 119-135; Myers, 1984, 575-592; Welch, 1994).

Besides, the analysis using the break-even point is also used when making operational decisions and in the process of short-term decision-making (Kondratova \& Umrikhina, 2014, 28-35).

Since the application of the break-even point is related to taking into account a number of assumptions and limitations, some authors consider it to be "an instrument for exclusively short-term business decision-making in situations of an insufficient capacity utilization within a stable economic environment" (Riznić i Marjanović, 2011, 713). These authors believe that the analysis using the breakeven point is a suitable basic quantitative instrument for making short-term decisions due to its sublimity and the transparency of the presentation of the basic business parameters, such as revenues and costs. The authors, however, problematize the assumptions that form the basis of the traditional break-even point model, which will be discussed in more detail in Chapters 3 and 4. The cost structure (Janjić et al, 2010), as well as the way of accounting the calculation of a profit, (Riznić i Marjanović, 2011) also have a significant influence on the applicability of the breakeven point in an enterprise's business practice. The total costs composed of either dominantly fixed or dominantly variable costs will differently respond to a change in the production volume, and therefore to the construction of the break-even point (Janjić et al, 2010, 561). Besides, the analysis using the break-even point must take into account the coverage of all costs and the way of their categorization into the fixed and the variable components (Underwood, Bush \& Heath, 2009, 13-22). The analysis needs to take into consideration these assumptions (Guidry, Horrigan \& Craykraft, 1998, 74-86). The analysis of the breakeven point becomes even more complex in the case of the existence of several products, different production technologies, the nonlinearity of revenues and costs, and the uncertainty of business doing (Chung, 1990, 1311-1328; Chung, 1993, 583-592), which in turn implies the possibility of the existence of more than one break-even point for the different values of the basic categories of a CVP analysis (Yunker, 2001, 127149). These issues will be discussed in more detail in Chapter 4.

\section{TRADITIONAL BREAK-EVEN POINT MODEL}

\section{Classical and neoclassical theories and assumptions about designing the break-even point}

When elaborating the traditional model of the breakeven point, economic theoreticians started from a number of determinants originating from classical or neoclassical enterprise theory. What both theories have in common is that they are based on the view that there is no uncertainty and unpredictability. Business conditions are invariable, i.e. known in advance and foreseeable, for which reason decision-makers may be fully, perfectly informed. Decision-makers 
have timely and correct information on all possible alternatives and are not time-limited in the decisionmaking process. Apart from that, decision-makers behave rationally, i.e. they are able to rationally decide and select the best solution. Managers, therefore, have no problems in choosing the most favorable alternative. The selection of the most favorable alternative is, on its part, related to the achievement of the main and only goal in the enterprise, namely the maximization of a profit (Sikavica, Bebek, Skoko i Tipurić, 1999, 83).

However, there are differences between classical and neoclassical theories. Classical theory assumes the existence of a single objectively correct decision, whereas neoclassical theory assumes the existence of several potentially correct decisions, only one of which is the best (Sikavica et al, 1999, 51). The best decision should result in the maximization of a profit, whereas such maximum profit is gained in the situation when, i.e. with the production volume at which, marginal income and marginal costs become equal. The described marginal principle of microeconomics applies to both short- and long-term profit maximization. Short-term profit maximization implies a profit maximization in the long term (Nikolić, 2000, 369-371). The treatment of the longterm as a simple sum of the individual short-term periods of business doing is possible since, let us not forget that fact, the basic assumption of the described theories says that there is no change in business conditions.

From the assumptions of classical and neoclassical theories related to market invariability and the stability of the internal and external environments, a profit maximization as the main goal, perfect information and the rationality of decision-makers and the equalization of the short- and long-term ways of decision-making, the assumptions of the traditional break-even point model are derived (Keat \& Young, 2003, 184).

The assumptions pertaining to the traditional model are as follows:

- Total costs only consist of absolutely fixed and proportionally variable costs and, therefore, develop linearly;
- The total income is equated with the value of the realized production;

- There is no change in the manufacturing capacity, the product range and market prices;

- The enterprise's economic result is only affected by a change in the quantity of manufactured products;

- All values are observed in a short period of time.

Total costs only consist of absolutely fixed and proportionally variable costs and, therefore, develop linearly. Total costs only consist of the two components: absolutely fixed and proportionally variable costs (Šunjić-Beus, Stavrić i Berberović, 2005, 161). Fixed costs do not change with changes in the degree of the capacity utilization and their level is determined when the manufacturing capacity is put in place. It is assumed that the capacity is not expanded and thus relatively fixed costs are nonexistent. Variable costs - the costs of the basic and accessory materials, labor in production etc. must also be directly proportional to the realized production volume. Thus, variable costs must be proportionally variable. There are no progressively variable, digressively variable or relatively fixed costs, i.e. in the event of a possible occurrence of the listed cost components, special procedures of linearization are used in order to reduce them to the linear components - proportionally variable and absolutely fixed. This is the reason for the assertion that the function of total costs is always linear and that the cost structure is invariable. These assumptions related to the linearity and invariability of the structure were aimed at avoiding a complication of the model, which would occur on the occasion of establishing and forecasting the course of relatively fixed costs and unproportionally variable costs. Besides, the linearity of the total cost function allows for a simple determination of the cost level and structure for an unknown, greater production volume, and the simpler monitoring and control of the cost level.

The total income is equated with the value of the realized production. The total income is treated as the value of the realized production and calculated as the multiple of the produced and sold products and the sale price. 
Thus, only regular, operating income, i.e. the income generated through the sales of the final products, is taken into consideration. Extraordinary income is not taken into account, and neither is financial and capital income, since their inclusion in the model would make the design of the break-even point difficult. Besides, it is assumed that the enterprise does not own stocks of such final products, i.e. that all manufactured products were sold on the market in the same period. The described assumption allows for the determination and comparison of all the revenues and costs of the same period. It is also assumed that the price at which products are sold on the market in the observed period is fixed. The size of the total income, therefore, only depends on the quantity of the products sold on the market. This relationship is directly proportional, i.e. an increase in the sales of products for one unit will result in an increase in the total income for one unit.

There is no change in the production capacity, the product range or market prices. Theoreticians assume that no change will occur in the size and degree of the utilization of the production capacity. For this reason, there are no relatively fixed costs, i.e. fixed costs are constant. It is also assumed that there is no change in the product range. The invariability of the capacity and the product structure results from the assumption that there are no significant changes in market supply and demand for products, or changes in consumers' preferences. Theoreticians go a step further, and in order to construct the break-even point model more easily, they assume the existence of homogenous production, i.e. only one kind of the products that the enterprise manufactures. Moreover, both the sale prices for the final products and the purchase prices of production factors are invariable. Therefore, the functions of, primarily variable, costs are proportional to the volume of the realized production.

The enterprise's economic result is only affected by a change in the quantity of the realized products. Consequent to the described assumptions of the invariability of the capacity, the sale price, the structure of the product range, the nonexistence of financial and extraordinary income and costs, a change in the level of costs and income is only due only to a change in the quantity of manufactured and sold products. It has already been pointed out that the total income and costs are only equated with operating income and costs.

All values are observed in a short period of time. All income and costs are observed in a selected, shortterm period. Each observed period is viewed in isolation and a long term is only a sum of numerous short periods. Basically, it means that the neoclassical theory does not recognize the long term. The short term is a fundamental prerequisite for the capacity, sales and demand, sale and purchase prices, the product mix and consumers' preferences to be constant. A short term is also a prerequisite for a linear course of the function of the total income and total expenses. Indeed, theoreticians believe that, over a shorter time period, one can detect the production interval in which costs and income really behave linearly. In the literature, such an interval is called the relevant range.

Based on the described assumptions, the traditional break-even point model presented in Figure 1 can be constructed.

\section{Cost classification}

In order to successfully construct the break-even point and carry out a corresponding analysis, it is necessary that costs should be classified into their fixed and variable components, respectively. A successful cost classification relates to a prior detailed analysis aimed at determining cost behavior. According to most economists, determining cost behavior is the biggest problem in designing an analysis using the breakeven point.

\section{Assumptions about a successful cost classification}

G. Riedel $(1975,28)$ lists the three assumptions about a successful cost classification into fixed and variable components:

- costs should be classified based on the type of a cost and the point at which a cost was incurred (cost centers); 


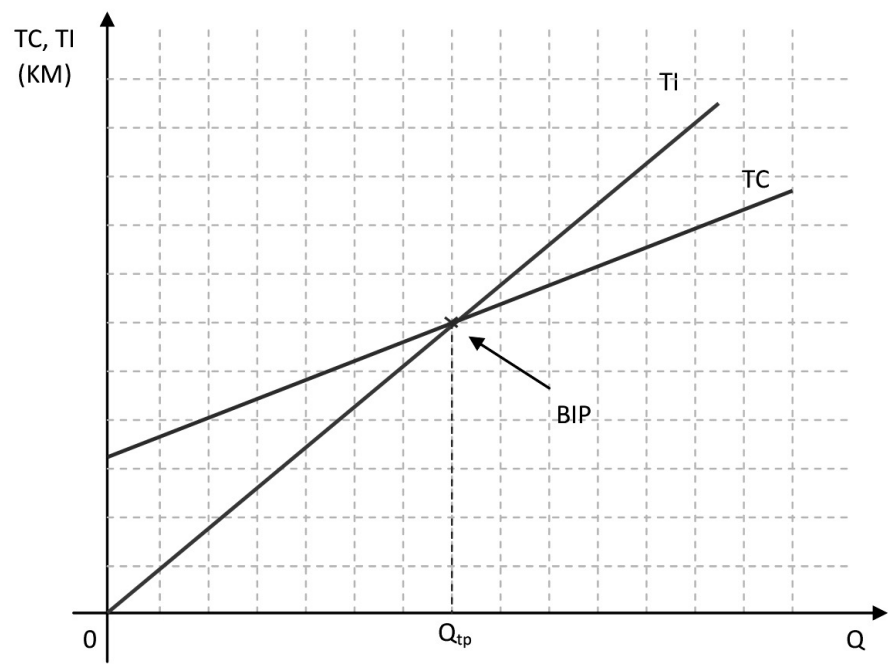

$\mathrm{TI}$ - the total income, TC - total costs, Q - the quantity of the realized products, Qtp - the quantity of the realized products at the break-even-point, BIP - the break-even-point

Figure 1 The traditional break-even point model

Source: Santini, 1999, 174

- the classification should begin from secondary cost centers;

- whether the fundamental assumptions relate to the manner in which costs were incurred, i.e. if cost drivers still apply, should be examined;

Costs should be classified based on the type of a cost and the point at which a cost was incurred (cost centers). This assumption forms the basis for a successful cost classification since it is necessary for the determination of a number of facts, such as: that individual cost centers have different cost "burdens", i.e. that they participate in total costs in different percentages, and also that different measurement units are used for expressing individual parts of the capacity, i.e. cost centers (e.g. kilograms, tons, hours, etc.). Besides, individual types of products are often manufactured in different varieties, i.e. their structure and composition change. It is also a fact that individual types of costs differently respond to changes in the degree of the capacity utilization in different cost centers (Riedel, 1975, 28-29). Due to all of the listed facts, it is necessary to be very much cautious when determining the cost center and the nature of particular types depending on cost centers, cost bearers, and the way to respond in an individual (different) situations.

The classification should begin from secondary cost centers. The identification of costs in secondary (nonmanufacturing) cost centers (the service department and overheads) and their transfer to primary (manufacturing) cost centers is a standard procedure for a cost calculation and defining the cost price of the final products in cost accounting. Before the very procedure of transferring costs to primary cost centers, it is necessary to accurately classify the costs of secondary centers into their fixed and variable components and add fixed components to the fixed costs of manufacturing centers and variable ones to the variable costs of the manufacturing plant.

The examination of the fundamental assumptions related to the way in which costs were incurred and cost drivers. It frequently happens that the once established 
assumptions and measurement units related to cost drivers are not subjected to critical examination, and as such are used over years. Naturally, changes in market conditions, the way of business doing and applied technologies require occasional reviews of the defined base values and their correction to a lesser or greater extent (Martinović, 2013, 42-45).

In his theoretical discussions, J. Dean (1952) also pays particular attention to the prerequisites that must be satisfied in order to classify costs successfully, particularly so in the conditions of a variable environment. He believes that (Dean, 1952: in Martinović, 2013, 42-45):

- obtaining relevant business data requires the selection of the year's period to be observed. Besides, one should bear in mind that the selected observation period should be typical, i.e. relatively stable, and that it should best reflect the trends of the key variables. Naturally, data comparability is important as well.

- when selecting factors for the analysis, one should be careful about the selection of the fundamental categories - income, costs and the production volume - and the significant factors that have an effect on the listed components. For the sake of obtaining comparable data, it is often necessary to simplify the model components, naturally not at the expense of the accuracy and relevance of the results.

- the issue of measuring the level of activities is related to monitoring and classifying costs in enterprises with a significant depth and breadth of the product range. The use of input and output indices is one of possible solutions.

\section{Cost classification methods}

There are different methods for cost classification. In economic practice, there is a mention of the application of different calculation methods, statistical tools, bookkeeping records and estimates and graph techniques. We will opt for the following classification of the methods, which includes:
- Experience-Based Observation and Estimation Method,

- Bookkeeping Method, and

- Mathematical-Statistical Methods.

The frequency of the application of these methods was empirically studied in a research study conducted in Bosnia and Herzegovina. This topic will be discussed in more detail in the empirical section of the paper.

Experience-Based Observation and Estimation Method The observation and estimation method attempts to estimate the nature of each individual cost and the way it responds to a change in the production volume. Cost observation and estimation are closely related to the decision-maker's experience and rely upon data bookkeeping and accounting. It is for this reason that this method is discussed as a whole with the bookkeeping method. Some theoreticians consider these two methods as a single one. "Indeed, both methods are founded on the estimation of the cost nature based on their behavior with respect to a change in the production volume, i.e. the size of the utilized capacity. The estimate is related to decision-makers' previous experience in monitoring costs, and to the ability of the accounting system to monitor and analyze costs" (Riedel, 1975, 36). Some theoreticians believe that observation is used if there are usual, regular costs, whereas estimation is used in the situation of forecasting future costs, as well as unusual, extraordinary costs. This method is considered to be one of the simplest.

Bookkeeping Method - The continuous and thorough monitoring of business developments and the analysis of an account in the ledger book are aimed at breaking down total costs into fixed and variable. In the process, semi-variable and relatively fixed costs are broken down into their absolutely fixed and absolutely variable components, respectively. Its success requires the following conditions to be met (Riedel, 1975, 198):

- the continuous and detailed accounting monitoring of business developments and changes, and a detailed accounting analysis; in this respect, a detailed cross-section of accounts in the ledger on the same basis in a period longer than one year is required; 
- relative invariability in the level of salaries, material prices, the capacity size, technology, etc.;

- an experience with the high level of the fluctuation of the production volume.

Mathematical-statistical methods - They are considered to be the most exact methods for cost classification and linearization and for designing dynamic and statistical break-even point models. There is a great number of mathematical-statistical methods: the interpolation method, the trend line method, the least square method (Turk, 1971; Markovski, 1983, 82-91), statistical analysis, the engineering approach (Dean, 1952, 195); the algebraic and graphical methods (Riedel, 1975, 29).

Economic theoreticians believe that none of the listed cost classification methods is sufficient and that combining the given methods is required for obtaining the best results.

\section{MODERN BREAK-EVEN POINT MODELS}

The traditional break-even point model assumed the invariability of the cost structure and level, the existence of only the nonlinear cost components and, among other things, the invariability of the sale price. In reality, however, these assumptions only apply to the short term. Over a longer time period, it is realistic to expect a change in costs, the emergence of the nonlinear components, a change in the sale price, and so forth.

Assuming a possibility of a change in the listed key variables the traditional break-even point method relies on leads us to the designing of complex, i.e. modified forms of the break-even point, in which case the break-even point models that include (Schweitzer \& Trossmann, 1998, 55-56):

- change in fixed costs,

- change in variable costs,

- change in the sale price, and

- the nonlinear structure of income and costs.
The listed models originate from the modern economic theories - behavioral and situational theories - which assume the existence of uncertainty and risk in business doing. Uncertainty and risk mean that an enterprise's environment is variable, i.e. in designing a break-even point model, a change in the key indicators that the concept of the break-even point relies on must be assumed. This leads to modifications related to a change in fixed and variable costs, the sale price, the product range, the cost structure, and so on. In the continuation of the paper, the most complex form of the model modification - the nonlinear breakeven point model - is explained.

\section{The break-even point model assuming the nonlinearity of the cost function and the income function}

The traditional break-even point model assumes the existence of the linear course of the development of the total income and costs. This assumption can also be applied to contemporary business conditions, though with the assumption of a relatively stable environment and the observation of values in the short term. In this case, when functions are linear, it is relatively easy to design the break-even point, i.e. it is relatively easy to forecast its development in the future. However, if the existence of the nonlinear course of the development of the cost function and the income function is assumed, the calculation of the break-even point for the enterprise becomes more complex, although the theoretical calculation principle remains the same: the break-even point is still the point at which the curves of costs and income intersect. Complexity is reflected in the fact that an enterprise may have problems in planning the breakeven point given the fact that it can hardly forecast the development of total costs and the total income due to the nonlinearity of their constituent components.

Thus, if it is assumed that total costs consist of both absolutely fixed and proportionally variable costs and progressively and digressively variable and relatively fixed costs, the result will be the nonlinear course of the development of total costs. However, the nonlinearity of the income function is not a rare 
phenomenon, either. Enterprises often make a price differentiation for a known client or approve such a client a quantity discount. Besides, in order to gain competitive advantages as a form of a competitive struggle, companies often resort to the so-called price competition.

Enterprises strive to eliminate competition, prevent new competitors from entering the market, increase or maintain their market share by lowering the prices for their products. Lowering prices is also frequently related to the so-called product life-cycle. The products that have been on the market for a long time and are no longer attractive to buyers are sold at lower prices. A sale at low prices is also very frequent in the situation when an enterprise changes its product range, i.e. when it removes some products from it or wants to sell, i.e. get rid of the surplus stocks or slowselling stocks from the warehouse. A sale of products at lower prices is frequent in the enterprises that are trying to penetrate a market, i.e. in those striving to gain as great a market share as possible or attract customers to buy their product which is brand new on the market or which has a characteristic (functional, design-related, etc.) distinguishing it from those launched by the competition. In this case, we speak about lowering the sale price. Besides, an enterprise may decide to increase the price for such products if it believes that its products are characterized by the top performance, i.e. if they offer customers a better way to satisfy their needs compared to the competition. In the same vein, the companies that sell luxury products intentionally launch products at higher prices due to the profile of the customers who are willing to pay more if a product will raise their status and become a status symbol (luxury cars - a Porsche; bags - a Louis Vuitton; diamond jewelry).

The enterprises that do not have competitors (monopolies) or manufacture specific products unique on the market opt for higher prices for their products. Naturally, the management of an enterprise may increase their prices in order to increase the total income independent of the enterprise's position based on market research and the business strategy. In any case, regardless of whether companies decide to increase or decrease prices for their products, the aim of an upward or downward price correction should be achieving an increase in the total sales income and gaining the target profit. However, the management of the enterprise are never sure that the correction of their prices will achieve the said goal. A price decrease may result in a loss, the same as a price increase may lead to a decline in the sale of a product and lower income.

Naturally, all these options and results make the exact graphic presentation and forecasting of the break-even point more difficult. The income function may decline and grow, i.e. it may behave in different ways, depending on the business policy, decisions on decreasing or increasing prices and the different ways in which the market and customers respond to these changes. In the same manner, the cost function can have a relatively unpredictable course of development.

However, if we assume that the function of total costs undergoes the three known zones, namely the digression, optimality and progression zones, respectively (Bogetić, 1995), on the one hand, and that a decrease in the total income, i.e. the fact that digression accompanies a higher degree of realization (which is the most frequent case in practice due to lower demand, i.e. market saturation with products), on the other, the lower and upper break-even points can be presented by means in Figure 2 .

The Figure 2 shows a decline in income and a nonlinear increase in costs at a higher degree of the capacity utilization. However, business decisions and operations in the enterprise may be closely mutually related and affect each other. Their mutual dependence may result in significant corrections in the break-even point model since they may affect the components of the total income and total costs, respectively, in different ways. The described changes of the income and the cost components over time testify to pronounced issues in the calculation of the exact break-even point in enterprises in contemporary business conditions.

We can conclude that there is not one single production volume where total costs and the total income become equal; there are rather two volumes, 


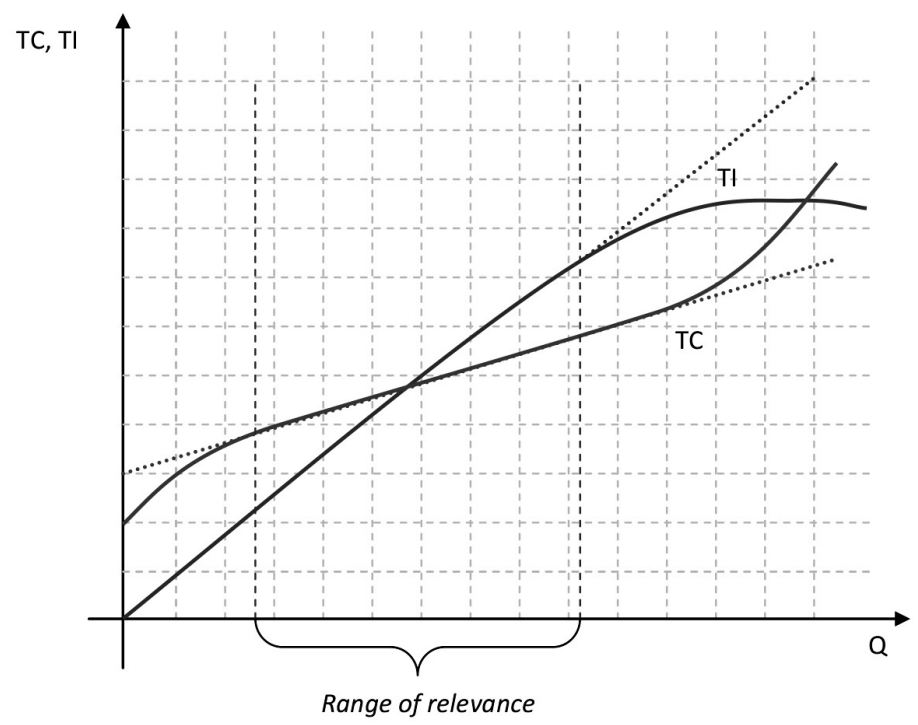

Figure 2 The break-even point with the nonlinear course of the development of the total income and costs Source: Dvorski i Luža, 2007, 189

instead, and the accurately defined production range where business doing is economical - between the two described intersections of the functions.

The most favorable situation for an enterprise occurs both when the lower break-even point is achieved at the lowest possible degree of the capacity utilization and when the span between the two break-even points is great. This situation implies a high degree of business certainty and leaves enough room for the management to make business decisions on production, sale, sale prices, etc.

If an enterprise operates between the two breakeven points, it achieves a positive financial result. Operation at a degree of the capacity utilization higher than the upper break-even point and lower than the lower break-even point implies a loss.

In the former case, the loss results from the high fixed costs that cannot be covered with the income from realized production, whereas in the latter, it results from the progression of the (variable and relatively fixed) costs that exceed the level of the gained income.

Beside these break-even points, the third such point, the so-called optimum point, is described in the literature. This point is found between the lower and the upper break-even points, and represents the situation when unit average and marginal costs become equal, and the unit financial result is maximum (Majcen, 1971, 116-146).

\section{Assumptions about the application of modern break-even point models}

When discussing assumptions about a successful cost classification, theoretician J. Dean (1952, 200203) attempts to answer the questions as to how to successfully analyze different factors and simplify calculations with the smallest possible errors and deviations. He creates the conditions for constructing modern variants of analysis using the break-even point based on dynamic factors and uncertainty factors.

A successful analysis of the break-even point and the cost classification itself requires appropriate answers to the following questions (Martinović, 2013, 111-119):

- How to select the observation period? 
- Which factors should be taken into account during the analysis?

\section{Selection of the observation period}

That the selected observation period should not be longer than one year has already been indicated. Apart from that, when selecting the observation period, the following should be taken into consideration (Dean, 1952, 200):

- the selected period should best reflect the necessary stability in the cost behavior and the level of the cost fluctuation;

- accounting data must be comparable during the period of the analysis;

- there must be independent fluctuations in demand and the production volume in order to allow a broad area for the observation of both types of costs and the volume;

- the number of such selected units of analysis (statistical units in the sample) - most often months - must be such that the same allow for conducting a valid statistical analysis.

Thus, these requirements refer to the need for the selection of a sufficiently long observation period, in which the relationship between the production volume and costs would be relatively stable, i.e. the one in which the occurrence of the extraordinary circumstances causing the emergence of unusual, unplanned costs would be minimized. These requirements are, naturally, aimed at establishing the standard values of costs and their nature, excluding various deviations in the cost behavior, so as to allow their classification aimed at achieving more successful management.

\section{Essential factors and the type of the estimate contained in data}

Upon defining the cost observation period, one question should be posed: what should be estimated, i.e. which factors should be taken into account when monitoring costs?
Indeed, as has already been indicated, it is necessary to profile the obtained data in order to eliminate different kinds of deviations. J. Dean (1952) discusses different kinds of corrections in raw data. However, a certain caution is necessary in the very procedure of singling out costs and their elimination, since it may happen that such an elimination includes the values significant for a certain phenomenon or signalizing some future phenomena and events.

In this respect, J. Dean $(1952,200)$ says: "The attempt to fully remove causes of data distortion in the costsproduction relationship is expensive and time-consuming. Therefore, shortcuts using the same basic statistical method for bridging some of the described distortions are mostly welcome in developing the analysis using the breakeven point. However, it is still dangerous to make small cuts without knowing where it leads. It is necessary to understand the steps - corrections that must be simplified or eliminated."

A number of problems and difficulties may arise when correcting raw (collected) data. We will list the common (Dean, 1952, 201):

- determining the basis for valuation, i.e. the basis for a cost estimate,

- selecting the costs included in the analysis,

- correcting cost and price values,

- estimating the time gap between recording information on costs, and the output which contains costs, and

- estimating special and nonrecurring data.

The determination of the basis for a cost valuation/estimate implies a periodical review and correction of the cost estimate and monitoring. When an enterprise operates in a turbulent environment, it is necessary that the estimate of the cost level and the course of development in the future and future prices should be included in the break-even point analysis. Managers should construct several kinds and variants of analysis using the break-even point, based on both the present and planned data and projections of the development of the sale and purchase prices. 
The selection of the costs that will be included in the analysis. The traditional break-even point model implies the inclusion of the costs of the absolutely fixed and proportionally variable character in the analysis, i.e. the linearization of the nonlinear components. Modern break-even point models imply the inclusion of the nonlinear components in the analysis as well. However, since the break-even point can be defined in different ways and for different purposes, the selection of costs is made based on the desired goal. Different purposes require different concepts of costs and different graphs of the break-even point. The greatest flexibility in modifying a graph so that it can serve its purpose will be achieved if components are analyzed individually, so that they can be combined according to the need - the purpose and needs of the concept, and included in the construction of different analyses using the break-even point. A problem may arise when individual types of costs are included in the analysis, particularly those that have a semivariable character and a dominantly fixed character. In this case, it would be desirable to break down such individual types of costs and relate them to the given activity, the cost driver. Thus, it would be useful to determine the part of each individual cost that has a dominantly fixed or a dominantly variable character, not necessarily according to the production volume, but rather according to the level of the given activity. It is generally believed that it would be desirable to construct several individual break-even points for each managerial unit and only include in the analysis the costs that are controllable at that managerial level. If the income function is included, only the profit gained and controllable at that level should be taken into account.

The correction of the changes in the cost price (costs) made in the past. In the analysis using the break-down point, a problem may include the effects of a change in the purchase price of production elements - the object of labor and labor itself - on the total costs or individual cost components. One of the possible solutions would be to relate such costs to the measures of the activities expressed in physical measurement units or in the base monetary values. However, there is a problem in the situation when individual cost types are expressed in several different measurement units. The best cost correction would resort to the monitoring of individual cost components and the factors affecting them as the basis for determining which prices affect which factors. Automatically, a change in corresponding prices would directly affect the corresponding cost components. Thus, a correction should be made in each cost component for a change in the related price. These corrections are aimed at allowing for a comparison of all costs expressed in the monetary units of the same value, e.g. in dollars in 2018.

A late estimate - the estimate of the time gap between the moment of manufacturing the final products, the cost center and obtaining data about costs. In this case, it is necessary to synchronize costs with the belonging production volume.

Theoreticians believe that this problem in both the cost analysis itself and the break-even point analysis is not paid due attention to (Markovski, 1983, 228-230). It is particularly important to bear in mind the time synchronization of production and costs in situations when:

- there is a longer time period of observation when it is essential to determine the individual characteristics and types of costs;

- the length of the production cycle is compared with the length of the period of cost recording;

- (the break-even point analysis) uses input or output indices.

Nonrecurring costs - one-time costs - The next problem in cost analysis and conducting a realistic analysis using the break-even point is the emergence of unplanned, extraordinary costs. One-time costs disturb data on costs and make them an unrealistic basis for the projection of relationship costs - the production volume. It would be best to use estimates and previous experiences as the basis for their elimination from the mass of total costs. However, the problem is in their connection with other costs, as well as the dilemma related to their "one-timeness". Indeed, the costs that were incurred extraordinarily and are unplanned can be treated as the costs incurred occasionally, or only in extraordinary circumstances. However, the 
question arises if this is really the case, i.e. whether an enterprise will face certain types of unplanned costs more often in the future. Thus, their nonrecurrence and unrepeatability are questionable, and their onetimeness and unrepeatability become questionable. Besides, determining untypical data itself may also be a problem, particularly so in the enterprises where each period seems untypical (Martinović, 2008).

"Learning costs and error costs should be eliminated using historical data. However, it is difficult to do in practice. Each period seems untypical. At times, the use of scatter diagrams with the sound knowledge of the facts that occurred over a month may result in singling out untypical data. However, this procedure is risky and may lead to extremely subjective conclusions" (Dean, 1952, 203).

\section{AN EXAMPLE FROM BUSINESS PRACTICE}

The research into the application of the traditional and modern break-even point models was conducted on a sample of 100 manufacturing enterprises in Bosnia and Herzegovina through verbal surveying and in-depth interviews. The questionnaire consisted of 25 survey questions, grouped into the five areas examining the role of the break-even point in an enterprise, the way of organizing and designing the analysis using the break-even point, the implementation obstacles in conducting the analysis, the areas of the application of the break-even point, and the dynamic and stochastic aspects of the analysis and its application in solving complex business problems. The large enterprises accounted for $18 \%$ of the sample, whereas the small accounted for $43 \%$. The other enterprises belonged to the category of medium-sized enterprises. The survey included 66 enterprises from the Federation of Bosnia and Herzegovina and 34 enterprises from the Republic of Srpska. The obtained results were processed by applying the descriptive statistics methods.

\section{Research results}

Of all the surveyed enterprises, 57\% regularly applied the analysis using the break-even point, whereas
$25 \%$ of them applied it occasionally. The frequency of conducting the analysis using the break-even point in Bosnian and Herzegovinian enterprises (as per industry) is shown in Table 1 (Martinović, Veselinović i Mangafić, 2019).

The enterprises that applied the analysis using the break-even point occasionally $(25 \%$ of the respondents) or regularly (57\% of the respondents) highlighted the following essential or extremely essential purposes, namely: the role of the breakeven point in the business performance analysis (54\%); making a decision on the cost-effectiveness of introducing new products $(46 \%)$; the replacement of the existing products with new ones (51\%); phasing out the production of certain products (44\%); making investment decisions (56\%); determining liquidity $(49 \%)$; and the planning and control of the existing results (48\%).

The research has confirmed the assumption that managers are aware of the concept of the breakeven point and its potentials. Irrespective of the geographical distribution and the industry, the majority of the enterprises apply the break-even point as a useful instrument for determining the necessary quantity and the value of the realized products needed to cover incurred costs.

The research has confirmed the research hypothesis H1.

A successful application of the break-even point model depends on a number of assumptions; therefore, the theoretical section of the paper highlights the issue of a proper cost classification (the modalities of separating costs), as well as the awareness of the existence and frequency of the nonlinearity of revenues and costs.

In this respect, the hypotheses $\mathrm{H} 2$ and $\mathrm{H} 3$ were tested.

The tabular presentation of the respondents' replies pertaining to the listed hypotheses, i.e. to the frequency of costs classification, problems at classifying costs and the way to classify costs, is given below (Tables 2, 3 and 4). 
Table 1 The frequency of conducting the analysis using the break-even point

\begin{tabular}{l|cccc}
\hline $\begin{array}{l}\text { Do you conduct the analysis using the break-even } \\
\text { point in your enterprise? }\end{array}$ & Yes & Occasionally & No & Total \\
\hline Textile industry & $8(53 \%)$ & $4(27 \%)$ & $3(20 \%)$ & $15(100 \%)$ \\
Furniture production & $8(50 \%)$ & $7(44 \%)$ & $1(6 \%)$ & $16(100 \%)$ \\
Production of milk and dairy products & $4(50 \%)$ & $2(25 \%)$ & $2(25 \%)$ & $8(100 \%)$ \\
Mineral water production & $2(100 \%)$ & $0(0 \%)$ & $0(0 \%)$ & $2(100 \%)$ \\
Bread and pastry production & $12(67 \%)$ & $2(11 \%)$ & $4(22 \%)$ & $18(100 \%)$ \\
Production of builders' joinery & $2(75 \%)$ & $1(25 \%)$ & $0(0 \%)$ & $3(100 \%)$ \\
Production of builders' joinery and elements & $6(86 \%)$ & $1(14 \%)$ & $0(0 \%)$ & $7(100 \%)$ \\
Building material production & $2(67 \%)$ & $1(33 \%)$ & $0(0 \%)$ & $3(100 \%)$ \\
Production of nonalcoholic beverages & $3(75 \%)$ & $1(25 \%)$ & $0(0 \%)$ & $4(100 \%)$ \\
Production of concrete products & $3(50 \%)$ & $1(17 \%)$ & $2(33 \%)$ & $6(100 \%)$ \\
Wood-processing industry & $2(40 \%)$ & $0(0 \%)$ & $3(60 \%)$ & $5(100 \%)$ \\
Other manufacturing industries & $5(38 \%)$ & $5(38 \%)$ & $3(24 \%)$ & $13(100 \%)$ \\
\hline Total: & $57(57 \%)$ & $25(25 \%)$ & $18(18 \%)$ & $100(100 \%)$ \\
\hline
\end{tabular}

Source: Author

The research results (Table 2) revealed that over one-half of the respondents (55\%) had noticed the need to classify costs for the purpose of their easier monitoring, i.e. for the needs of constructing the break-even point. As many as $80 \%$ of the respondents (Table 3) pointed out the fact that they faced the problem of cost classification, particularly so when costs are mixed (nonlinear, semi-variable), and if there are mixed costs in the production of several types of products. With respect to cost classification methods (Table 4), the bookkeeping method - i.e. using bookkeeping data and records to classify costs - prevails. The methods of experience-based estimation and the mathematical-statistical method and specialized software were used to a lesser extent.

Tables 5 and 6 provide a tabular presentation of the respondents' replies pertaining to the listed hypotheses, i.e. to the existence of the awareness of the nonlinearity of revenues and costs, and problems when estimating future revenues and costs arising from their nonlinearity.

With respect to the managers' views of the nonlinearity of income and costs, the majority of the respondents $(70 \%)$ believe that the nonlinearity of income and costs is very frequent. Besides, the percentage of the respondents $(22 \%)$ who believe that income nonlinearity is more frequent than cost nonlinearity $(14 \%)$ is slightly higher.

Although the majority of the respondents believe that nonlinearity is very frequent, as many as $43 \%$ of the respondents believe that they can accurately estimate future income and costs both for a short and for a long period of time. Due to business uncertainty, $47 \%$ of the respondents believe that an accurate estimate of future income and costs is only possible only for the short term, whereas $6 \%$ of the respondents believe that such an accurate estimate is not possible at all.

The research results have revealed that managers have problems when classifying costs and estimating future revenues and costs and their (non)linearity (H3), and that there is the awareness of finding modalities for a proper cost classification and estimation of revenues and costs, at least for the short term $(\mathrm{H} 2)$.

The research study has shown that, in practice, enterprises can lesser and lesser rely on plan and deterministic data. Entering actual, current data in the break-even point analysis contributes to the accuracy and flexibility of the model, although it also makes the process of collecting and processing 
Table 2 The frequency of cost classification

\begin{tabular}{c|cccccc}
\hline Do you classify costs into fixed and variable? & Yes & Occasionally & No & $\begin{array}{c}\text { Does not know / does not want } \\
\text { to respond }\end{array}$ & Total \\
\hline & $55 \%$ & $30 \%$ & $11 \%$ & $4 \%$ & $100 \%$ \\
\hline
\end{tabular}

Source: Author

Table 3 Problems at cost classification

\begin{tabular}{l|ccccc}
\hline $\begin{array}{l}\text { Do you face problems } \\
\text { at cost classification? }\end{array}$ & $\begin{array}{c}\text { Yes, they are } \\
\text { difficult to } \\
\text { classify }\end{array}$ & $\begin{array}{c}\text { Yes, it is difficult to classify } \\
\text { costs in the case of mixed } \\
\text { costs }\end{array}$ & $\begin{array}{c}\text { Yes, in the case of } \\
\text { shared costs for } \\
\text { several products }\end{array}$ & $\begin{array}{c}\text { Does } \\
\text { not } \\
\text { know }\end{array}$ & \begin{tabular}{c} 
Total \\
\hline
\end{tabular} \\
\hline $24 \%$ & $31 \%$ & $25 \%$ & $5 \%$ & $15 \%$ & $100 \%$ \\
\hline
\end{tabular}

Source: Author

Table 4 The ways to classify costs

\begin{tabular}{l|lll}
\hline In what way do you classify costs? & Yes & No & Total \\
\hline Through observation and estimation, based on experience & $29 \%$ & $71 \%$ & $100 \%$ \\
By applying the bookkeeping method & $51 \%$ & $49 \%$ & $100 \%$ \\
By applying a mathematical-statistical method & $22 \%$ & $78 \%$ & $100 \%$ \\
\hline
\end{tabular}

Source: Author

information more difficult. Indeed, a successful break-even point analysis requires the monitoring of changes in production (the depth and breadth of the product range), demand, the sale price, the level and structure of production costs and market risks, and the inclusion of the same in the analysis. This implies the use of dynamic and stochastic break-even point models.

The application of dynamic and stochastic models requires the knowledge of the complex mathematicalstatistical procedures aimed at quantifying uncertainty and risk, specialized software and the accounting-information system that will ensure accurate and timely information and allow for an objective determination and estimation of the cost and income components (Martinović et al, 2019). The implementation of the described prerequisites in business practice is an additional challenge for the management of Bosnian and Herzegovinian enterprises.

\section{Implications, research potentials and limitations of the research study}

The research study carried out on one hundred manufacturing enterprises in Bosnia and Herzegovina was aimed at presenting familiarity with the concept of the break-even point, its assumptions and the level of its implementation in Bosnian and Herzegovinian enterprises. The value of the paper also includes the fact that it is one of few recent studies of the concept of the break-even point and its applicability in the business practice of manufacturing enterprises in Bosnia and Herzegovina.

Both the empirical and the theoretical sections of the paper pay particular attention to the potentials of the traditional break-even point model, as well as to the possibilities of the elaboration and practical use of the contemporary models based on the estimates of the nonlinearity of revenues and costs. Although the paper highlights the deficiencies and rigidity of 
Table 5 The nonlinearity of costs and income

\begin{tabular}{|c|c|c|c|c|c|c|c|}
\hline $\begin{array}{l}\text { Nonlinearity of the } \\
\text { total income and } \\
\text { costs is frequent? }\end{array}$ & Yes & $\begin{array}{l}\text { Income nonlinearity } \\
\text { is more frequent than } \\
\text { cost nonlinearity }\end{array}$ & $\begin{array}{l}\text { Cost nonlinearity is } \\
\text { more frequent than } \\
\text { income nonlinearity }\end{array}$ & $\begin{array}{l}\text { Nonlinearity is } \\
\text { not frequent }\end{array}$ & No & $\begin{array}{l}\text { Does not } \\
\text { know }\end{array}$ & Total \\
\hline & $34 \%$ & $22 \%$ & $14 \%$ & $8 \%$ & $4 \%$ & $18 \%$ & $100 \%$ \\
\hline
\end{tabular}

Source: Author

Table 6 The estimation of future costs and income

\begin{tabular}{|c|c|c|c|c|c|}
\hline $\begin{array}{l}\text { Do you estimate future } \\
\text { income and costs and } \\
\text { the break-even point? }\end{array}$ & $\begin{array}{l}\text { Yes, although for a shorter } \\
\text { period due to business } \\
\text { risks and uncertainty }\end{array}$ & $\begin{array}{l}\text { Yes, for both } \\
\text { short and long } \\
\text { periods }\end{array}$ & $\begin{array}{l}\text { No, due to } \\
\text { significant risks }\end{array}$ & $\begin{array}{l}\text { Does not know/ } \\
\text { does not want to } \\
\text { respond }\end{array}$ & Total \\
\hline & $47 \%$ & $43 \%$ & $6 \%$ & $4 \%$ & $100 \%$ \\
\hline
\end{tabular}

Source: Author

the classical concept of the break-even point, it also highlights its advantages. It is its simplicity that makes it valuable as an instrument for efficient, fast and simple decision-making. This was also demonstrated by the research done in the surveyed Bosnian and Herzegovinian enterprises. Most of those enterprises (regardless of their size and industry) use the model in its simplest, traditional form either as a separate or as an accessory instrument.

The advantage of the research study is related to the research methodology - a combination of the questionnaire and the in-depth interview, which allowed for a detailed explanation of the questions and responses and the clarification of possible uncertainties between the interviewer and the interviewee.

Certainly, the limitations of the research study need to be pointed out, namely reflecting in a relatively small number of the participants and the size of the enterprises (small and medium-sized enterprises prevail). Besides, the research study only focused on manufacturing enterprises in order to obtain the natural (quantitative) indicators of the break-even point. Finally, the focus was on testing a part of the assumptions about the application of the analysis using the break-even point (primarily the issues of cost classification), as well as familiarity with the primarily traditional break-even point model in business practice. For the purpose of interpreting the results, the simplest methods of descriptive statistics were used.

In terms of future studies, future studies should be aimed at expanding the sample to a greater number of enterprises and focusing on assumptions about the application of complex, contemporary, dynamic and stochastic methods of analysis. The analysis using the break-even point obviously shows its reach and limitations when enterprises do business in an unpredictable and changing environment. In such conditions, only contemporary models can satisfy the enterprises' requirements. Besides, a future research study should include research into the sustainability and reality of a number of assumptions about the application of the break-even point in the conditions of the nonexistence of perfect competition, change in market conditions (supply, demand, prices, competitors' activity) and a change in the product range and the production capacity. A comprehensive observation of all these factors and their synergy, as well as their impact on the determination of the breakeven point, is a very demanding and challenging task for future research to do. 


\section{CONCLUSION}

The concept of the break-even point is a well-known instrument of classical economic theory in the literature on microeconomics. Although it is a concept that was present in the economic literature as early as in the late 19th century, it is applied in business practice even today. By all means, in the present business environment characterized by uncertainty and risk, the break-even point model must be modified and adjusted to contemporary business conditions. Modifications imply the inclusion (in the model) of assumptions about a change in the key variables both fixed and variable costs, the sale price, the total income, the contribution of coverage, and so forth or, as a result of the described changes, the existence of the nonlinear course of the development of the functions of the total income and total costs. In order to design a correct and accurate break-even point model which will illustrate the actual relations and values of such key variables, it is necessary to make a proper estimate and selection of costs, select the relevant key variables observation period and include all the essential analysis factors in the calculation. These activities will very frequently result in dynamic and stochastic break-even point models as the only relevant forms of the break-even point analysis in the conditions of risk and uncertainty.

\section{REFERENCES}

Bogetić, G. (1995). Ekonomika preduzeća. Podgorica, Crna Gora: Obod-Cetinje.

Chung, K. H. (1990). Output decision under demand uncertainty with stochastic production function: A contingent claims approach. Management Science, 36(11), 1311-1328.

Chung, K. H. (1993). Cost-volume-profit analysis when the firm has production flexibility. Journal of Business, Finance and Accounting, 20(4), 583-592. doi.org/10.1111/j.1468-5957.1993. tb00276.x

Dean, J. (1952). Methods and Potentialities of Break-Even Analysis. London, UK: David Solomons.
Dvorski, S. i Luža, F. (2007). Poslowna ekonomija. Varaždin, HR: TIVA Tiskara.

Gean, F., \& Gean, V. (2015). The desirability of an integrated learning methodology for enriching CVP analysis. Journal of Business and Accounting, 8(1).

Guidry, F., Horrigan, J. O., \& Craycraft, C. (1998). CVP analysis: A new look. Journal of Managerial Issues, 10(1), 74-85.

Janjić, V., Todorović, M. i Jovanović, D. (2010). CVP analiza uticaja troškovne strukture na dobit preduzeća. Ekonomske teme, 48(4), 547-562.

Keat, G. P., \& Young, K. Ph. (2003). Managerial Economics. New Jersey, USA: Prentice Hall.

Kilger, W. (1993). Flexible Plankostenrechnung und Deckungsbeitragsrechnung. Wiesbaden, D: Gabler.

Kondratova, S. V., \& Umrikhina, M. V. (2014). CVP analysis as a tool for effective company management in the new economy. Economic Analysis: Theory and Practice, 34.

Majcen, Ž. (1971). Troškovi u teoriji i praksi privrednih organizacija. Zagreb, HR: Informator.

Markovski, S. (1983). Troškovi u poslovnom odlučivanju. Zagreb, HR: Informator.

Martinović, D. (2008). Tačka pokrića kao instrument poslovnog odlučivanja. Neobjavljena doktorska disertacija, Ekonomski fakultet Univerziteta u Sarajevu, Sarajevo, BiH.

Martinović, D. (2013). Primjena tačke pokrića u poslownoj praksi bosanskohercegovačkih preduzeća. Sarajevo, BiH: Ekonomski fakultet Univerziteta u Sarajevu.

Martinović, D., Veselinović, Lj. i Mangafić, J. (2019). Istraživanje praksi kontrolinga u bosanskohercegovačkim preduzećima. Paper presented at the 11th scientific and professional conference with international participation "Quality 2019“, Neum, $\mathrm{BiH}$.

McCabe, G. M. (1979). The empirical relationship between investment and financing: A new look. Journal of Financial and Quantitative Analysis, 14, 119-135. doi.org/10.2307/2330658

Mehar, A. (2005). The financial repercussion of cost, revenue and profit: An extension in the BEP and CVP analysis. Applied Financial Economics, 15(4), 259-271. doi. org/10.1080/0960310042000314205 
Myers, S. C. (1984). The capital structure puzzle. The Journal of Finance, 39(3), 575-592.

Nikolaevič, B. A. (2015). Methodological aspects of applying the CVP-analysis concept under economic crisis. International Accounting, 18(43), 18-35.

Nikolić, M. (2000). Ekonomika preduzeća. Beograd, RS: Ekonomski fakultet Univerziteta u Beogradu.

Riedel, G. (1975). Deckungsbeitragsrechnung - Wie aufbauen, wie nutzen? Stuttgart, D: Taylorix Fachverlag.

Riznić, D. i Marjanović, P. (2011). Ograničenja CVP analize i prelomne tačke rentabiliteta za potrebe poslovnog odlučivanja. Ekonomske teme, 49(4), 713-726.

Santini, I. (1999). Troškovi u poslovnom odlučivanju. Zagreb, HR: HIBIS doo, Centar za ekonomski consulting.

Schweitzer, M., \& Trossmann, E. (1998). Break-even-Analysen Methodik und Einsatz. Berlin, D: Duncker \& Humbolt.
Sikavica, P., Borna, B., Skoko, H. i Tipurić, D. (1999). Poslovno odlučivanje. Zagreb, HR: Informator.

Šunjić-Beus, M., Stavrić, B. i Berberović, Š. (2005). Ekonomika preduzeća. Sarajevo, BiH: Ekonomski fakultet Univerziteta u Sarajevu.

Turk, I. (1971). Računovodstvene informacije kao podloga za donošenje poslownih odluka. Zagreb, HR: Informator.

Underwood, J. H., Bush, R. P., \& Heath, W. C. (2009). Picture the numbers: A conceptual illustration of linking marginal reasoning, marketing actions, and pro forma CVP analysis with a spreadsheet picture. Journal for Advancement of Marketing Education, 14, 13-33.

Yunker, J. A. (2001). Stochastic CVP analysis with economic demand and cost functions. Review of Quantitative Finance and Accounting, 17(2), 127-149. doi:10.1023/a:1017921620718

Welch, I. (1994). The cross-sectional determinants of corporate capital expenditures: A multinational comparison. UCLA Working Papers.

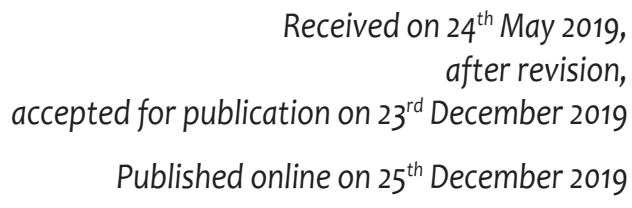

Danijela Martinovic is an Associate Professor at the Department of Microeconomics at the School of Economics and Business, University of Sarajevo. She obtained her Ph.D. degree at the School of Economics and Business in Sarajevo. Fields of her interest include microeconomics, operational management and public policies. 